\title{
Nitrous oxide emissions in a winter wheat - summer maize double cropping system under different tillage and fertilizer management
}

\author{
M. Huang, T. Liang \& L. Wang \\ Key Laboratory of Land Surface Pattern and Simulation, Institute of Geographical Sciences and Natural Resources Research, \\ Chinese Academy of Sciences, Beijing 100101, China
}

\begin{abstract}
An accurate estimation of nitrous oxide $\left(\mathrm{N}_{2} \mathrm{O}\right)$ emission from 110 million ha of upland in China is essential for the adoption of effective mitigation strategies. In this study, the effects of different tillage practices combined with nitrogen $(\mathrm{N})$ fertilizer applications on $\mathrm{N}_{2} \mathrm{O}$ emission in soils were considered for a winter wheat (Triticum aestivum L.) - summer maize (Zea mays L.) double cropping system. Treatments included conventional tillage plus urea in split application (CTF1), conventional tillage with urea in a single application (CTF2), no-tillage with straw retained plus reduced urea in a split application (NTSF1) and no-tillage with manure plus reduced urea in a split application (NTMF1). The amounts of $\mathrm{N}$ input in each treatment were 285 and $225 \mathrm{~kg} \mathrm{~N} / \mathrm{ha}$ for wheat and maize, respectively. Both NTSF1 and NTMF1 were found to reduce chemical N fertilizer rates by $33.3 \%$ (wheat) and 20\% (maize), respectively, compared to CTF1 and CTF2. $\mathrm{N}_{2} \mathrm{O}$ emissions varied between 3.2 (NTSF1) and 9.9 (CTF2) $\mathrm{kg} \mathrm{N} \mathrm{N}_{2} \mathrm{O}-\mathrm{N} /$ ha during the wheat season and between 7.6 (NTFS1) and 14.0 (NTMF1) $\mathrm{kg} \mathrm{N} \mathrm{N}_{2} \mathrm{O}-\mathrm{N} /$ ha during the maize season. The yield-based emission factors ranged from 21.9 (NTSF1) to 60.9 (CTF2) g N $2 \mathrm{O}-\mathrm{N} / \mathrm{kg} \mathrm{N}$ for wheat and 92.5 (NTSF1) to 157.4 (NTMF1) g $\mathrm{N}_{2} \mathrm{O}-$ $\mathrm{N} / \mathrm{kg} \mathrm{N}$ for maize. No significant effect of the treatments on crop yield was found. In addition to reducing production costs involved in land preparation, NTSF1 was shown to decrease chemical fertilizer input and mitigate $\mathrm{N}_{2} \mathrm{O}$ emissions while sustaining crop yield.
\end{abstract}

Keywords: Conventional tillage, no-tillage, nitrous oxide emission, urea, straw retained, manure

\section{Introduction}

Agriculture is estimated to contribute $36 \%$ of the total anthropogenic $\mathrm{N}_{2} \mathrm{O}$ emission in China, with approximately $0.275 \mathrm{Tg} \mathrm{N}_{2} \mathrm{O}-\mathrm{N}$ released per annum from cropland in $1990 \mathrm{~s}$ (ADB-GEF-UNEF, 1998). However, there are large uncertainties associated with these estimates related to the cropping system, soil type, timing and method of fertilizer application and climate (Snyder et al., 2009). China has approximately 140 million ha of cropland, of which 110 million ha and 30 million ha are in the form of upland-crop land and paddy fields, respectively. Although nitrous oxide emissions from rice fields and rice-winter wheat rotation systems in southern and south-eastern China have been well

Correspondence: T. Liang. E-mail: liangt@igsnrr.ac.cn; L. Wang. E-mail: wanglq@igsnrr.ac.cn

Received December 2013; accepted after revision November 2014 studied (Liu et al., 2010), only a few studies have directly addressed $\mathrm{N}_{2} \mathrm{O}$ emissions from fertilized upland soils.

The North China Plain (NCP) is one of China's major breadbaskets, with annual double cropping of winter wheat and summer maize forming the dominant cropping system in the area. A relatively large rate of chemical $\mathrm{N}$ fertilizer $(\sim 256-450 \mathrm{~kg} \mathrm{~N} / \mathrm{ha})$ is usually applied in a cropping sequence (He et al., 2009). $\mathrm{N}$ application in excess of crop uptake capacity is a driver of increased $\mathrm{N}_{2} \mathrm{O}$ emission. Residual nitrogen left in the soil from the previous cropping season can exacerbate the effect on $\mathrm{N}_{2} \mathrm{O}$ flux (Kim et al., 2013). The large $\mathrm{N}$ application rates in double cropping will inevitably cause an increase in area-based $\mathrm{N}_{2} \mathrm{O}$ emission. At present, however, there is limited information available concerning the timing of $\mathrm{N}_{2} \mathrm{O}$ emissions during the winter period in the NCP (Holst et al., 2008).

Increasingly no-tillage (NT) has been adopted in the NCP, and the practice has been found to increase $\mathrm{N}_{2} \mathrm{O}$ loss from soils compared with conventional tillage (CT) (Mackenzie 
et al., 1998). However, other studies have suggested that NT can decrease or produce negligible effects on $\mathrm{N}_{2} \mathrm{O}$ loss (Elmi et al., 2003). These contrasting results may originate from differences in factors, such as water-filled porosity, soil temperature and texture, levels of available carbon and nitrate, and the distribution of microbial populations and potential enzyme activities (Linn \& Doran, 1984). The effect of NT on $\mathrm{N}_{2} \mathrm{O}$ loss during crop rotations in the NCP has seldom been investigated.

Urea application during NT is seeing increased use in combination with straw or manure amendments. NT and other CT practices have the potential to enrich the soil organic carbon pool by increasing residue and manure inputs and decreasing $\mathrm{C}$ loss (Baker et al., 2006). However, these practices may also enhance $\mathrm{N}_{2} \mathrm{O}$ emission, which offsets gains in soil C storage (Robertson et al., 2000; Wang \& Dala, 2006). Therefore, it is necessary to include the $\mathrm{N}$ in straw and manure as a crop nutrient to reduce the use of mineral $\mathrm{N}$ fertilizer in the NT systems. There is currently a lack of integrated assessments of these combined applications (i.e. NT with $\mathrm{N}$ management), and a limited understanding of their role in reducing $\mathrm{N}_{2} \mathrm{O}$ loss and agronomical feasibility in the NCP.

\section{Materials and methods}

\section{Site description}

A field experiment was conducted from October 2009 to June 2010 near Dezhou City $\left(36^{\circ} 56^{\prime} \mathrm{N}, 116^{\circ} 36^{\prime} \mathrm{E}\right)$ of Shandong Province, China beginning 2009.10-2010.6, 7 yr after initiation of the long-term NT study in October 2003. The soil is this area is classified as a Calcaric fluvisol, formed from the sediments from the Yellow River. The soil is calcareous, alkaline and rich in phosphorus and potassium. The surface soil has a silt loam texture (sand, 13\%; silt, $65 \%$; clay, 22\%), according to the USDA classification system, a $\mathrm{pH}$ value of 7.9 and contains $29 \mathrm{~g}$ organic $\mathrm{C} / \mathrm{kg}$ and $3.1 \mathrm{~g}$ total $\mathrm{N} / \mathrm{kg}$ in the top $20 \mathrm{~cm}$. Winter wheat is usually planted in October, while summer maize is planted in June. The mean annual precipitation in this area is $585 \mathrm{~mm}$, most of which occurs during the rainy months of July-August.

\section{Field experiment design}

The variation in $\mathrm{N}_{2} \mathrm{O}$ emissions was determined in the field under different tillage and fertilizer $\mathrm{N}$ practices commonly used in the NCP. Four combinations of tillage and N treatments were included in the study. All treatments consisted of equivalent total $\mathrm{N}$ inputs, namely $285 \mathrm{~kg} \mathrm{~N} / \mathrm{ha}$ for winter wheat and $225 \mathrm{~kg} \mathrm{~N} /$ ha for summer maize, with $\mathrm{N}$ originating from different sources. Under the CT system, urea was divided into applications with $95 \mathrm{~kg} \mathrm{~N} / \mathrm{ha}$ as the fertilizer and the remaining as supplementary fertilizer for wheat and then for maize during the early growth period (CTF1). For the second CT system, urea was applied in a single pre-plant application before sowing wheat and then surface applied at planting for maize (CTF2). Basal fertilizer for wheat was incorporated via rototiller in the top $20 \mathrm{~cm}$ of soil for both CT treatments. Under the NT system, the N sources included maize straw (95 kg N/ha) and urea (190 kg N/ha) for wheat, with wheat straw (45 kg N/ha) and urea (180 kg N/ha) for maize (NTSF1). Other treatments consisted of poultry manure $(95 \mathrm{~kg} \mathrm{~N} / \mathrm{ha})$ and urea (190 kg N/ha) for wheat with the manure (45 kg N/ha) and urea $(180 \mathrm{~kg} \mathrm{~N} / \mathrm{ha}$ ) for maize (NTMF1). In the winter wheat system, maize straw and poultry manure were surface applied in early spring. Urea was surface applied in two equal parts in late October and early spring of the following year for winter wheat and as a single application during the early growth period for maize. The poultry manure contained $22.5 \mathrm{~g} / \mathrm{kg}$ total $\mathrm{N}$ and $4.1 \mathrm{~g} / \mathrm{kg}$ alkali-hydrolysis $\mathrm{N}$. The mean total $\mathrm{N}$ contents were 7.5 and $9.6 \mathrm{~g} / \mathrm{kg}$ for winter wheat straw and maize straw, respectively. For the NTSF1 treatment, the maize straw was applied at $10 \mathrm{Mg} / \mathrm{ha}$ in late March for winter wheat and at $6.0 \mathrm{Mg} / \mathrm{ha}$ for wheat straw after sowing maize. For the NTMF1 treatment, poultry manure was applied at $4.2 \mathrm{Mg} / \mathrm{ha}$ in late March for winter wheat and at $2 \mathrm{Mg} /$ ha after sowing maize. Details of field operations during the experiment are shown in Table 1. Three replicates of each treatment were established using a randomized block design with each plot measuring $7.5 \times 40 \mathrm{~m}$.

Winter wheat was seeded in rows at an interval of $20 \mathrm{~cm}$ and a rate of $180 \mathrm{~kg} / \mathrm{ha}$ on 28 October, 2009. Maize was planted at a density of 66400 plants per ha in rows at an interval of $60 \mathrm{~cm}$ without tillage on 27 June 2010. Winter wheat was irrigated using a surface flooding method with a water meter on 3 December 2009, 28 March 2010 and 15 April 2010 (75 mm water on each occasion).

Fluxes of $\mathrm{N}_{2} \mathrm{O}$ were measured using the static chamber method following Chang et al. (1998). A field measurement was conducted once or twice per month during the period from December to March, and once per week during the period from March to November. Two chambers were installed per plot to provide duplicate measurements. Sampling events lasted for $30 \mathrm{~min}$ (total of 4 samples taken every $10 \mathrm{~min}$ ) and were conducted between 09:00 and 11:30 h (Beijing time). The concentration of $\mathrm{N}_{2} \mathrm{O}$ in samples was determined using a gas chromatograph HP-4890D equipped with an electron capture detector. Daily average $\mathrm{N}_{2} \mathrm{O}$ fluxes and cumulative $\mathrm{N}_{2} \mathrm{O}$ fluxes for cropping seasons were calculated (Lemke et al., 1999). Soil temperature at a depth of $10 \mathrm{~cm}$ was measured in triplicate at each sampling occasion using digital thermometers. Soil bulk density samples were also collected 1-2 times per month from each plot using cores $(6 \mathrm{~cm}$ tall by $6 \mathrm{~cm}$ diameter) collected from 
Table 1 Crops grown and fertilizers used during the experiment in the rotation year (October 2009-June 2010)

\begin{tabular}{|c|c|c|c|c|c|c|c|c|c|c|}
\hline \multirow[b]{3}{*}{ Treatment } & \multicolumn{6}{|c|}{ Winter wheat } & \multicolumn{4}{|c|}{ Summer maize } \\
\hline & \multicolumn{2}{|c|}{ 1st application } & \multicolumn{2}{|c|}{ 2nd application } & \multicolumn{2}{|c|}{ 3rd application } & \multicolumn{2}{|c|}{ 1st application } & \multicolumn{2}{|c|}{ 2nd application } \\
\hline & $\mathrm{kg} \mathrm{N} / \mathrm{ha}$ & Date & $\mathrm{kg} \mathrm{N} / \mathrm{ha}$ & Date & $\mathrm{kg} \mathrm{N} / \mathrm{ha}$ & Date & $\mathrm{kg} \mathrm{N} / \mathrm{ha}$ & Date & $\mathrm{kg} \mathrm{N} / \mathrm{ha}$ & Date \\
\hline CTF1 & 95 (Urea) & $25 / 10$ & 190 (Urea) & $28 / 03$ & & & & & 225 (Urea) & $12 / 07$ \\
\hline NTMF1 & 95 (Urea) & $25 / 10$ & 95 (Manure) & $27 / 03$ & 95 (Urea) & $28 / 03$ & 45 (Manure) & $28 / 06$ & 180 (Urea) & $12 / 07$ \\
\hline
\end{tabular}

the $0-20 \mathrm{~cm}$ layer. Soil bulk densities, along with water content measurements were used to calculate the water-filled pore space (WFPS) (Soil Survey, 1996). The concentrations of $\mathrm{NH}_{4}^{+}$and $\mathrm{NO}_{3}^{-}$were also measured (Buchkina et al., 2010). Daily ambient air temperature and precipitation data were collected from a meteorological station located $300 \mathrm{~m}$ away from the experimental site.

\section{Data analysis}

Differences in seasonal fluxes and cumulative emissions of $\mathrm{N}_{2} \mathrm{O}$ among treatments were evaluated using single-factor analysis of variances (ANOVA). Multiple comparisons of means were conducted with a Fisher's protected least significant difference (LSD) test $(P<0.05)$. In addition, the relationships between $\mathrm{N}_{2} \mathrm{O}$ emissions and environmental variables (WFPS, soil inorganic $\mathrm{N}$ content and air temperature) were evaluated using Spearman correlation analysis.

\section{Results and discussion}

\section{Nitrous oxide emission over the winter wheat season}

Nitrous oxide emissions increased following addition of urea to the soil in autumn (Figure 1a) and reach a peak in early November. Several weak peaks in emissions were also measured in April after irrigation. The largest emission rates of $\mathrm{N}_{2} \mathrm{O}$ from the CTF2 treatment were measured between November and March of the next year. The $\mathrm{N}_{2} \mathrm{O}$ flux rates were highly variable and ranged from 16.5 to $1049.7 \mu \mathrm{g}$ $\mathrm{N}_{2} \mathrm{O}-\mathrm{N} / \mathrm{m}^{2} \mathrm{~h}^{1}$ across all treatments. In this preliminary study, the average flux rate was between 52.2 and $57.1 \mu \mathrm{g}$ $\mathrm{N}_{2} \mathrm{O}-\mathrm{N} / \mathrm{m}^{2} \mathrm{~h}^{1}$.

During autumn (late October-November) the mean flux rates for different treatments increased in the order of CTF2 $>$ CTF1 $>$ NTMF1 > NTSF1 (Table 2). Emission of $\mathrm{N}_{2} \mathrm{O}$ from CTF2 was greater than that from CTF1 due to the larger quantity of urea applied in CTF2. $\mathrm{N}_{2} \mathrm{O}$ emissions from CT treatments were larger than those measured from either NT treatment.

During the winter period (December-March), the $\mathrm{N}_{2} \mathrm{O}$ emission rates varied between 24.4 and $246.3 \mu \mathrm{g} \mathrm{N}_{2} \mathrm{O}-\mathrm{N} /$ $\mathrm{m}^{2} / \mathrm{h}^{1}$, with mean emission rates following the same trend as rates calculated for autumn months (Figure 1a; Table 2). The soil temperatures at a depth of $10 \mathrm{~cm}$ ranged from -3.1 to $-1.1^{\circ} \mathrm{C}$ in four of six sampling events (Figure 2), indicating that denitrification and nitrification activities of micro-organisms produced $\mathrm{N}_{2} \mathrm{O}$ in frozen soils (Tenuta \& Sparling, 2011).

In spring (April-mid-June), the average $\mathrm{N}_{2} \mathrm{O}$ emission under NTMF1 was significantly greater than that of the other three treatments, likely due to organic C stimulating denitrification (Table 2). Fertilizer application following irrigation in mid-April resulted in a short-lived pulse of $\mathrm{N}_{2} \mathrm{O}$ in all treatments except NTMF1 (Figure 1a) and also coincided with the decrease in soil inorganic $\mathrm{N}$ content (Figure 1c,d). However, the peak in $\mathrm{N}_{2} \mathrm{O}$ emissions from NTMF1 after irrigation on 15 April extended into late-April and was greater than losses from urea application. These phenomena may be attributed to denitrification of easily degradable $\mathrm{C}$ compounds and the development of anaerobic microsites following manure application (Chadwick et al., 2000).

Over the entire growing period of wheat, mean $\mathrm{N}_{2} \mathrm{O}$ flux rates varied significantly among the four treatments in the order of CTF2 $>$ CTF1 > NTMF1 > NTSF1 (Table 2). As expected, CT treatments showed larger $\mathrm{N}_{2} \mathrm{O}$ emissions than NT treatments. Greater cumulative fluxes were recorded in winter than in autumn and spring in all treatments except NTMF1. From late autumn to March of the next year, the percentage of $\mathrm{N}_{2} \mathrm{O}$ emissions after application of one-third of $\mathrm{N}$ accounted for 61.0, 91.4, 60.4 and $42.2 \%$ of seasonal accumulated losses for CTF1, CTF2, NTSF1 and NTMF1 treatments, respectively. Therefore, the autumn-winter period was shown to be the 

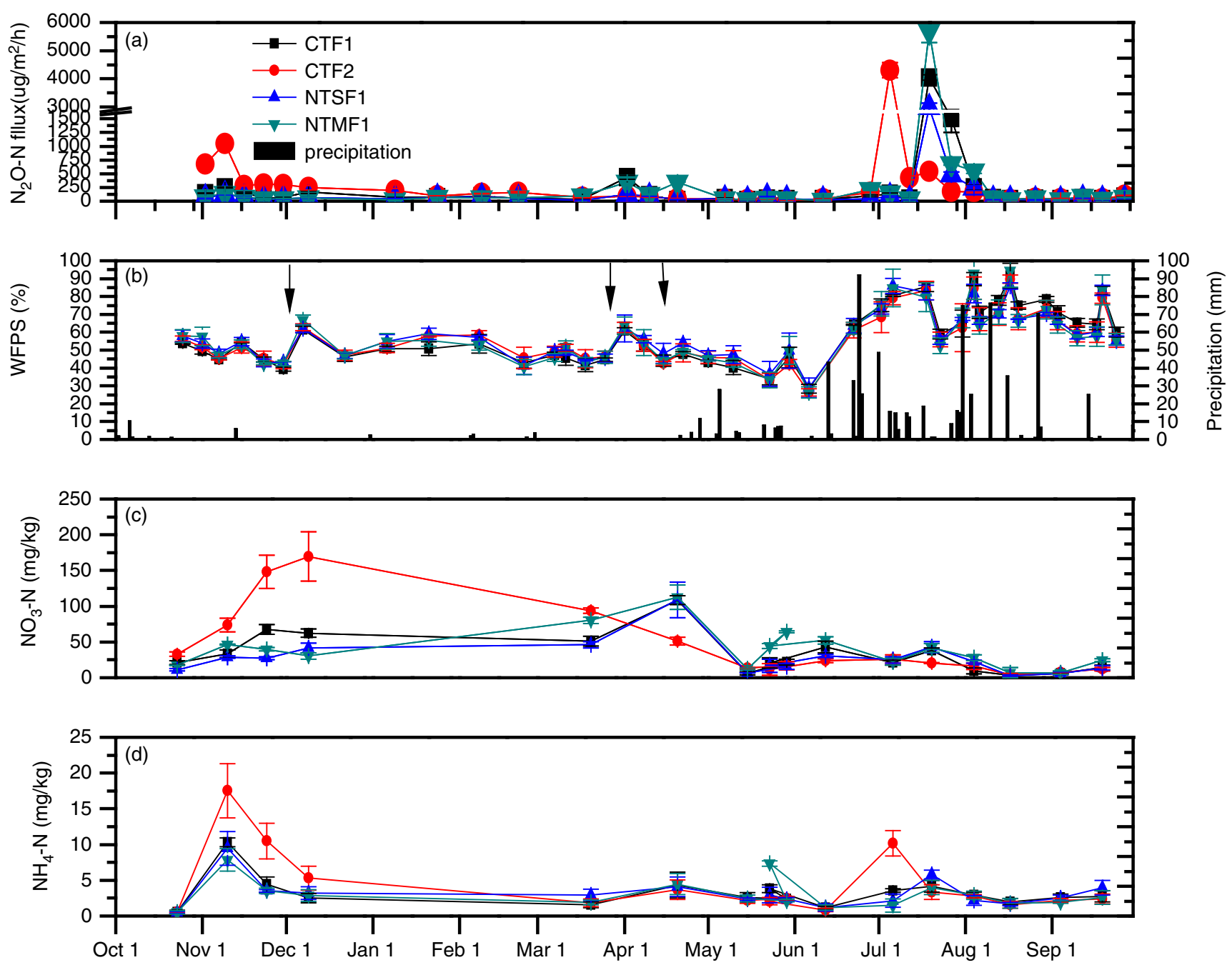

Figure 1 Environmental variables and $\mathrm{N}_{2} \mathrm{O}$ emissions during the rotation year. (a) $\mathrm{N}_{2} \mathrm{O}$ emissions (mean \pm standard error, $n=3$ ). (b) Precipitation (Vertical arrows denote time of irrigation) and soil water-filled pore space (SWFS, 0-20 cm depth) (mean \pm standard error, $n=3$ ). (c) Soil mean $\mathrm{NO}_{3}-\mathrm{N}$ and (d) $\mathrm{NH}_{4}-\mathrm{N}$ concentrations (mean \pm standard error, $n=3$ ). CTF1, CTF2, NTSF1 and NTMF1 refer to conventional tillage with mineral $\mathrm{N}$ in split application, conventional tillage with mineral $\mathrm{N}$ in a single dose, no-tillage with straw retained and reduced mineral $\mathrm{N}$ in split application, and no-tillage with additions of manure and reduced mineral $\mathrm{N}$ in split application.

largest contributor to $\mathrm{N}_{2} \mathrm{O}$ emissions from fertilized wheat systems in the NCP.

The temporal pattern of $\mathrm{N}_{2} \mathrm{O}$ emissions tended to correspond with that of $\mathrm{NO}_{3}-\mathrm{N}$ levels in the upper 0-20 cm (Figure 1a,c). However, no correlation was found between daily $\mathrm{N}_{2} \mathrm{O}$ flux rates and soil $\mathrm{NO}_{3}^{-}$content over the same depth range (Table 3). Daily $\mathrm{N}_{2} \mathrm{O}$ flux (log-transformed) was positively correlated with soil $\mathrm{NH}_{4}^{+}$content in the upper $0-20 \mathrm{~cm}$ except with NTMF1. During peaks in $\mathrm{N}_{2} \mathrm{O}$ emission, $\mathrm{NH}_{4}-\mathrm{N}$ content decreased, while $\mathrm{NO}_{3}-\mathrm{N}$ content increased, suggesting that nitrification had occurred after urea application (Figure 1c,d). Daily $\mathrm{N}_{2} \mathrm{O}$ fluxes (logtransformed) for CTF1, NTSF1 and NTMF1 plots were positively correlated with WFPS at $0-20 \mathrm{~cm}$ except with the CTF2 treatment (Table 3). $\mathrm{N}_{2} \mathrm{O}$ emission from CTF2 plots was mainly controlled by the amount of urea, which was nonlinearly related to increasing $\mathrm{N}$ input (Kim et al., 2013).

$\mathrm{N}_{2} \mathrm{O}$ flux rates were negatively correlated with air temperature for all treatments, with a significant correlation found only for treatment CTF2 (Table 3). Peak emissions of $\mathrm{N}_{2} \mathrm{O}$ with the CTF2 treatment occurred at lower air temperatures of 3.7$8.4^{\circ} \mathrm{C}$ (autumn) while lower $\mathrm{N}_{2} \mathrm{O}$ emissions were observed with higher air temperatures $\left(14.0-25.8^{\circ} \mathrm{C}\right)$ from April to June.

\section{Nitrous oxide emissions during summer maize season}

During the maize season, $\mathrm{N}_{2} \mathrm{O}$ emissions increased following fertilizer application, reached a peak within 1 week and then gradually declined over the following week (Figure 1a). The 
Table 2 Seasonal emission rates $\left(\mu \mathrm{g} \mathrm{N} \mathrm{N}_{2} \mathrm{O}-\mathrm{N} / \mathrm{m}^{2} \mathrm{~h}^{1}\right)$ and cumulative flow $\left(\mathrm{kg} \mathrm{N}_{2} \mathrm{O}-\mathrm{N} / \mathrm{ha}\right)$ of $\mathrm{N}_{2} \mathrm{O}$ emission from treated plots

\begin{tabular}{|c|c|c|c|c|c|}
\hline \multirow[b]{2}{*}{ Treatment } & \multicolumn{4}{|c|}{ Winter wheat } & \multirow{2}{*}{$\begin{array}{c}\text { Summer maize } \\
\text { Total }\end{array}$} \\
\hline & Autumn (Oct-Nov) & Winter (Dec-Mar) & Spring (Apr-June) & Total & \\
\hline CTF1 & $130.4 \mathrm{~b}$ & $76.1 \mathrm{~b}$ & $111.8 \mathrm{~b}$ & $101.8 \mathrm{~b}$ & $493.2 b$ \\
\hline CTF2 & $472.8 \mathrm{a}$ & $149.9 \mathrm{a}$ & $61.8 \mathrm{c}$ & $200.1 \mathrm{a}$ & $471.4 \mathrm{~b}$ \\
\hline $\operatorname{LSD}_{0.05}$ & 13.2 & 4.7 & 6.0 & 4.2 & 46.0 \\
\hline \multicolumn{6}{|c|}{ Cumulative flow } \\
\hline CTF1 & $1.19 \mathrm{Bb}$ & $2.21 \mathrm{Ab}$ & $2.17 \mathrm{~A}(0.18) \mathrm{b}$ & $5.6 \mathrm{~b}$ & $11.9 \mathrm{~b}$ \\
\hline CTF2 & $4.31 \mathrm{Aa}$ & $4.35 \mathrm{Aa}$ & $1.20 \mathrm{~B}(0.17) \mathrm{c}$ & $9.9 \mathrm{a}$ & $10.8 \mathrm{~b}$ \\
\hline NTSF1 & $0.58 \mathrm{Cd}$ & $1.40 \mathrm{Ad}$ & $1.24 \mathrm{~B}(0.08) \mathrm{c}$ & $3.2 \mathrm{~d}$ & $7.6 \mathrm{c}$ \\
\hline NTMF1 & $0.70 \mathrm{Cc}$ & $1.53 \mathrm{Bc}$ & $3.06 \mathrm{~A}(0.08) \mathrm{a}$ & $5.3 \mathrm{c}$ & $14.0 \mathrm{a}$ \\
\hline
\end{tabular}

Means in the same column followed by the same lower case letter and means in the same row followed by the same capital letter are not significantly different. $\mathrm{LSD}_{0.05}$ is the values of $5 \%$ L.S.D. for multiple comparisons. The values in parentheses are the $\mathrm{LSD}_{0.05}$ for multiple comparisons between autumn, winter and spring. LSD, least significant difference; CTF1, conventional tillage with mineral $\mathrm{N}$ in split application; CTF2, conventional tillage with mineral $\mathrm{N}$ in a single dose; NTSF1, no-tillage with straw retained and reduced mineral $\mathrm{N}$ in split application; and NTMF1, no-tillage with additions of manure and reduced mineral $\mathrm{N}$ in split application.

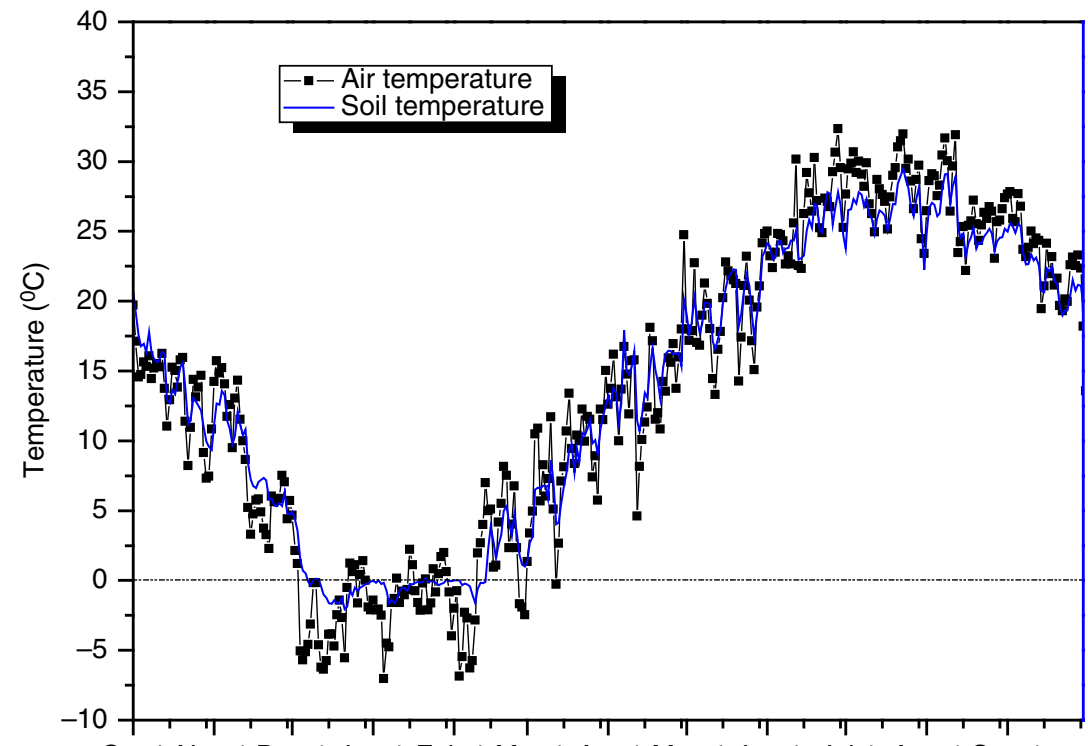

Oct 1 Nov 1 Dec 1 Jan 1 Feb 1 Mar 1 Apr 1 May 1 Jun 1 Jul 1 Aug 1 Sep 1
Figure 2 Air temperature and soil temperatures $(10 \mathrm{~cm} \quad$ depth $)$ during observation period. extremely large $\mathrm{N}_{2} \mathrm{O}$ emissions only lasted for approximately 7 days. The cumulative $\mathrm{N}_{2} \mathrm{O}$ losses from sowing to midAugust accounted for 92.9, 90.7, 92.0 and $93.7 \%$ of the total $\mathrm{N}_{2} \mathrm{O}$ emissions for CTF1, CTF2, NTSF1 and NTMF1, respectively. Liu et al. (2011) also found that high $\mathrm{N}_{2} \mathrm{O}$ emissions occurred for 41 days after fertilizer application in July.

Peak values of $\mathrm{N}_{2} \mathrm{O}$ emissions for the treatments were 4049.5, 4310.8, 2993.9 and $5682.8 \mu \mathrm{g} \mathrm{N} \mathrm{N}_{2} \mathrm{O}-\mathrm{N} / \mathrm{m}^{2} \mathrm{~h}^{1}$ for CTF1, CTF2, NTSF1 and NTMF1, respectively. These values are comparable to a previously reported value of $5516 \mu \mathrm{g} \quad \mathrm{N}_{2} \mathrm{O}-\mathrm{N} / \mathrm{m}^{2} \mathrm{~h}^{1}$ in a cropped soyabean system (Ciampitti et al., 2008). During the time period of postrainfall $\mathrm{N}_{2} \mathrm{O}$ peaks, WFPS were approximately $68.5 \%$ for CTF2 and $82.5 \%$ for the other three treatments plots (Figure 1b), respectively. Greater soil water content in upland soils usually restricted aeration and resulted in larger denitrification rates, as large values of WFPS together with the addition of $\mathrm{N}$ fertilizers tend to stimulate the microbial denitrifiers (Davidson, 1991). 
$\mathrm{N}_{2} \mathrm{O}$ emissions (log-transformed) for the four treatments were positively correlated with soil $\mathrm{NO}_{3}-\mathrm{N}$ and $\mathrm{NH}_{4}-\mathrm{N}$ in the surface layer (Table 3). However, soil $\mathrm{NO}_{3}-\mathrm{N}$ concentrations measured 1 week after urea surface application were relatively small (ca. $26.3 \mathrm{mg} \mathrm{NO} \mathrm{N}_{3}-\mathrm{N} / \mathrm{kg}^{1}$ in soil for $\mathrm{CTF} 2$ and $40 \mathrm{mg} \mathrm{NO}-\mathrm{N} / \mathrm{kg}$ in soil for the other three treatments) (Figure 1c). These results indicate that $\mathrm{N}_{2} \mathrm{O}$ emissions are more likely to depend on soil $\mathrm{N}$ turnover rather than mineral $\mathrm{N}$ pool size under dry-wet cycles during the summer season (Harrison \& Webb, 2001).

Different treatments produced significantly different mean $\mathrm{N}_{2} \mathrm{O}$ emission rates and cumulative $\mathrm{N}_{2} \mathrm{O}$ emissions (Table 2). The cumulative $\mathrm{N}_{2} \mathrm{O}$ emissions from NTMF1 were 17.6, 29.6 and $84.2 \%$ greater than those from CTF1, CTF2 and NTSF1, respectively. Several other factors also produced greater $\mathrm{N}_{2} \mathrm{O}$ emission in the NTMF1 plots. The addition of available $\mathrm{C}$ with manure increased denitrification of $\mathrm{NO}_{3}^{-}$ and NT with manure application also lengthened the period of $\mathrm{N}_{2} \mathrm{O}$ emission by the reduction of urea or loss of $\mathrm{NO}_{3}^{-}$ through surface runoff. The smaller $\mathrm{N}_{2} \mathrm{O}$ emissions observed under NTSF1 may have several causes, such as a decrease in urea application resulting in a decrease in $\mathrm{N}_{2} \mathrm{O}$ loss potential or immobilization of $\mathrm{N}$ following the addition of fresh wheat with a high $\mathrm{C} / \mathrm{N}$ ratio.

Table 3 Spearman correlation coefficients $(R)$ and $P$ values $(P)$ for $\mathrm{N}_{2} \mathrm{O}$ production and soil variables $(0-20 \mathrm{~cm})$ and average air temperature (AA)

\begin{tabular}{ccrcrr}
\hline Treatment & & $\mathrm{NO}_{3}-\mathrm{N}$ & $\mathrm{NH}_{4}-\mathrm{N}$ & $\%$ WFPS & \multicolumn{1}{c}{ AA } \\
\hline \multirow{2}{*}{ Winter wheat season } & & & & \\
CTF1 & $R$ & -0.11 & 0.73 & 0.61 & -0.29 \\
& $P$ & 0.82 & 0.06 & $<0.01$ & 0.25 \\
CTF2 & $R$ & 0.23 & 0.96 & 0.32 & -0.51 \\
& $P$ & 0.61 & $<0.01$ & 0.20 & 0.03 \\
NTSF1 & $R$ & -0.14 & 0.91 & 0.50 & -0.29 \\
& $P$ & 0.76 & $<0.01$ & 0.04 & 0.25 \\
NTMF1 & $R$ & 0.55 & 0.43 & 0.47 & -0.07 \\
& $P$ & 0.20 & 0.34 & 0.04 & 0.79 \\
Maize season & & & & & \\
CTF1 & $R$ & 0.88 & 0.762 & 0.19 & 0.38 \\
& $P$ & 0.02 & 0.08 & 0.54 & 0.20 \\
CTF2 & $R$ & 0.77 & 0.995 & 0.03 & 0.25 \\
& $P$ & 0.07 & $<0.01$ & 0.91 & 0.40 \\
NTSF1 & $R$ & 0.83 & 0.85 & 0.28 & 0.31 \\
& $P$ & 0.04 & 0.03 & 0.36 & 0.31 \\
NTMF1 & $R$ & 0.77 & 0.85 & 0.16 & 0.47 \\
& $P$ & 0.07 & 0.03 & 0.60 & 0.10 \\
\hline Spearman & & & & &
\end{tabular}

Spearman correlation analysis was performed using logarithmtransformed data of $\mathrm{N}_{2} \mathrm{O}$ flux and untransformed data of waterfilled pore space (WFPS), and untransformed data of $\mathrm{N}_{2} \mathrm{O}$ flux and $\mathrm{NO}_{3}-\mathrm{N}$ and $\mathrm{NH}_{4}-\mathrm{N}$ contents and air temperature observations. Treatments CTF1, CTF2, NTSF1 and NTMF1 are the same as in Table 1.

\section{Yield-based $\mathrm{N}_{2} \mathrm{O}$ emission factors}

The amount of $\mathrm{N}$ emitted as $\mathrm{N}_{2} \mathrm{O} / \mathrm{kg}$ from wheat and maize grains was calculated for each season using grain yield and grain $\mathrm{N}$ concentration (Pelster et al., 2011). Yield-based $\mathrm{N}_{2} \mathrm{O}$ emissions ranged from 21.0 to $60.9 \mathrm{~g} \mathrm{~N}_{2} \mathrm{O}-\mathrm{N} / \mathrm{kg} \mathrm{N}$ exported in grains for wheat and 92.5-157.4 $\mathrm{g} \mathrm{N}_{2} \mathrm{O}-\mathrm{N} / \mathrm{kg} \mathrm{N}$ exported in grains for maize (Table 4). The larger values for maize in the current study may be attributed to greater $\mathrm{N}_{2} \mathrm{O}$ losses and smaller $\mathrm{N}$ uptake due to rainy and cloudy days encountered during the maize grain-fill period. The emissions for maize were greater than the values of $6.6-22.7 \mathrm{~g} \mathrm{~N}_{2} \mathrm{O}$ / $\mathrm{kg} \mathrm{N}$ exported in maize grain reported by Pelster et al. (2011), but comparable to values of 50.7-134.7 g N ${ }_{2} \mathrm{O} / \mathrm{kg} \mathrm{N}$ exported in maize grain in the Beijing area (Liu et al., 2003). Similar to seasonal cumulative $\mathrm{N}_{2} \mathrm{O}$ emissions, the yieldbased $\mathrm{N}_{2} \mathrm{O}$ emissions displayed significant differences between treatments with NTSF1 producing the lowest emissions among treatments for both wheat and maize seasons.

There was no marked effect of treatment on wheat and maize yield or grain $\mathrm{N}$ uptake (Table 4). This suggests that the $27.45 \%$ reduction in urea application rates $(33.3 \%$ reduction for wheat and $20 \%$ for maize) did not affect the crop yields. Rather the reduction in urea application resulted in a decrease in $\mathrm{N}_{2} \mathrm{O}$ emissions of 38.29 and $47.83 \%$ for NTSF1 compared to CTF1 and CTF2, respectively. The decrease in urea input and increase in fertilizer efficiency along with the decreased production costs of land preparation under no-tillage represent a significant monetary savings to farmers. However, according the values of the

Table 4 Effect of treatment on crop yield $(\mathrm{kg} / \mathrm{ha}$, at $86 \%$ dry matter), grain $\mathrm{N}$ uptake $(\mathrm{kg} / \mathrm{ha})$ and yield-based $\mathrm{N}_{2} \mathrm{O}$ emission $(\mathrm{g}$ $\mathrm{N}_{2} \mathrm{O}-\mathrm{N} / \mathrm{kg}$ grain $\mathrm{N}$ )

Treatment Grain yield Grain $\mathrm{N}$ uptake Yield-based $\mathrm{N}_{2} \mathrm{O}$ emission

\begin{tabular}{|c|c|c|c|}
\hline \multicolumn{4}{|c|}{ Winter wheat season } \\
\hline CTF1 & 6582.3 & 150.1 & $39.4 b$ \\
\hline CTF2 & 6772.0 & 162.3 & $60.9 \mathrm{a}$ \\
\hline NTSF1 & 6445.0 & 153.9 & $21.0 \mathrm{c}$ \\
\hline NTMF1 & 6617.3 & 169.4 & $31.3 \mathrm{bc}$ \\
\hline $\mathrm{LSD}_{0.05}$ & ns & ns & 11.49 \\
\hline \multicolumn{4}{|c|}{ Summer maize season } \\
\hline CTF1 & 6858.9 & 77.7 & $154 \mathrm{ab}$ \\
\hline CTF2 & 7257.2 & 89.4 & $123 \mathrm{bc}$ \\
\hline NTSF1 & 7549.2 & 82.9 & $92.5 \mathrm{c}$ \\
\hline NTMF1 & 7522.6 & 90.8 & $157.4 \mathrm{a}$ \\
\hline $\mathrm{LSD}_{0.05}$ & ns & ns & 32.1 \\
\hline
\end{tabular}

Means in the same column followed by the same letter are not significantly different, and $\mathrm{LSD}_{0.05}$ is the value of $5 \%$ L.S.D. for multiple comparisons. Treatments CTF1, CTF2, NTSF1 and NTMF1 are the same as in Table 1. LSD, least significant difference. 
yield-based $\mathrm{N}_{2} \mathrm{O}$ emissions, CTF2 for wheat and NTMF1 for maize are expected to decrease. To avoid this decrease, results from this study show that farmers should consider applying manure only in the winter wheat season and straw in the maize season. Given that a large percentage of applied $\mathrm{N}$ was lost to ammonia volatilization and nitrate leaching following high nitrogen input in the NCP (Huang et al., 2011), the use of NTSF1 should be encouraged as the best management practices (BMP), as this treatment reduces $\mathrm{N}_{2} \mathrm{O}$ emissions without affecting crop yield.

\section{Conclusions}

Several peak emissions were associated with fertilizer application for wheat in autumn and maize from mid-July to early August. The percentage of $\mathrm{N}_{2} \mathrm{O}$ emissions after application of one-third of $\mathrm{N}$ ranged from $42.2 \%$ for NTMF1 to $91.4 \%$ for CTF2 during the winter period, while approximately $90.7-93.7 \%$ of the total $\mathrm{N}_{2} \mathrm{O}$ emissions for the four treatments occurred during maize sowing from late-June to mid-August. $\mathrm{N}_{2} \mathrm{O}$ emissions varied from 3.2 (NTSF1) to 9.9 (CTF2) $\mathrm{kg} \mathrm{N}_{2} \mathrm{O}-\mathrm{N} / \mathrm{ha}$ during the wheat season and from $7.6 \mathrm{~kg} \mathrm{~N} \mathrm{~N}_{2} \mathrm{O}-\mathrm{N} / \mathrm{ha}$ for NTFS1 to $14.0 \mathrm{~kg} \mathrm{~N} \mathrm{~N}_{2} \mathrm{O}-\mathrm{N} / \mathrm{ha}$ for NTMF1 during the maize season. There was no significant effect of treatment on crop yields. The yield-based emission factors ranged from 21.9 (NTSF1) to 60.9 (CTF2) g N $2 \mathrm{O}-\mathrm{N} /$ $\mathrm{kg} \mathrm{N}$ exported in wheat grains and from 92.5 (NTSF1) to 157.4 (NTMF1) g $\mathrm{N}_{2} \mathrm{O}-\mathrm{N} / \mathrm{kg} \mathrm{N}$ exported in maize grains. As expected, the practice of retaining crop residue together with a reduced urea rate under no-till (NTSF1) was shown to significantly mitigate $\mathrm{N}_{2} \mathrm{O}$ emissions while sustaining crop yield, in turn reducing production costs. NTSF1 treatment should therefore be encouraged in this region of China.

\section{Acknowledgements}

This study was sponsored by the National Natural Scientific Foundation of China (No. 40471110, 41171390 and 41401591) and the National Basic Research Program of China (973 Program) (2012CB417004). The authors also thank Professor Michael Goss and the anonymous reviewers for their constructive comments.

\section{References}

ADB-GEF-UNEF, 1998. Asia least-cost greenhouse gas abatement strategy manlia: Asian Development Bank.

Baker, J.M., Ochsner, T.E., Venterea, R.T. \& Griffis, T.J. 2006. Tillage and soil carbon sequestration-what do we really know? Agriculture, Ecosystems and Environment, 118, 1-5.

Buchkina, N.P., Balashov, E.V. \& Rizhiya, E.Y. 2010. Nitrous oxide emissions from a light-textured arable soil of North-western Russia: effects of crops of crops, fertilizers, manures amd climate parameters. Nutrient Cycling in Agroecosystems, 87, 429-442.
Chadwick, D.R., Paon, B.F. \& Brookman, S.E. 2000. Nitrous oxide and methane emissions following application of animal manures to grassland. Journal of Environment Quality, 29, 277-287.

Chang, C., Cho, C.M. \& Janzen, H.H. 1998. Nitrous oxide emission from long-term manured soils. Soil Science Society of America Journal, 62, 677-682.

Ciampitti, I.A., Ciarlo, E.A. \& Conti, M.E. 2008. Nitrous oxide emissions from soil during soybean [(Glycine $\max (\mathrm{L}$.$) Merrill)]$ crop phonological stages and stubbles decomposition period. Biology and Fertility of Soils, 44, 581-588.

Davidson, E.A. 1991. Fluxes of nitrous oxide and nitric oxide from terrestrial ecosystems. In: Microbial production and consumption of greenhouse gases: methane, nitrogen oxides and halomethanes (eds J.E. Rogers \& W.B. Whitman), pp. 219-235. Am Soc Microbiol, Washington, DC.

Elmi, A.A., Madramootoo, C., Hamel, C. \& Liu, A. 2003. Denitrification and nitrous oxide to nitrous oxide plus denitrogen ratios in the soil profile under three tillage systems. Biology and Fertility of Soils, 38, 340-348.

Harrison, R. \& Webb, J. 2001. A review of the effect of $\mathrm{N}$ fertilizer type on gaseous emissions. Advance in Agronomy, 73, 65-108.

He, P., Li, S.T., Jin, J.Y., Wang, H.T., Li, C.J., Wang, Y.L. \& Cui, R.Z. 2009. Performance of an optimized nutrient management system for double-cropped wheat-maize rotations in North-central China. Agronomy Journal, 101, 1489-1496.

Holst, J., Liu, C., Yao, Z., Bruggemann, N., Zheng, X., Giese, M. \& Butterbach-Bahl, K. 2008. Fluxes of nitrous oxide, methane and carbon dioxide during freezing-thawing cycles in an Inner Mongolian steppe. Plant and Soil, 308, 105-117.

Huang, M.X., Liang, T., Ou-yang, Z., Wang, L.Q., Zhang, C.S. \& Zhou, C.H. 2011. Leaching losses of nitrate nitrogen and dissolved organic nitrogen from a yearly two crops system, wheatmaize, under monsoon situations. Nutrient Cycling in Agroecosystems, 91, 77-89.

Kim, D.-G., Hernandez-Ramirez, G. \& Giltrap, D. 2013. Linear and nonlinear dependency of direct nitrous oxide emissions on fertilizer nitrogen input: a meta-analysis. Agriculture, Ecosystems and Environment, 168, 53-65.

Lemke, R.L., Izaurralde, R.C., Nyborg, M. \& Solberg, E.D. 1999. Tillage and $\mathrm{N}$-source influence soil-emitted nitrous oxide in the Alberta parkland region. Canadian Journal of Soil Science, 79, 1524.

Linn, D.M. \& Doran, J.W. 1984. Aerobic and anaerobic microbial populations in no-till and plowed soils. Soil Science Society of American Journal, 48, 794-799.

Liu, X.J., Ju, X.T., Zhang, F.S., Pan, J.R. \& Christie, P. 2003. Nitrogen dynamics and budgets in a winter wheat-maize cropping system in the North China Plain. Field Crops Research, 83, 111124.

Liu, S., Qin, Y., Zou, J. \& Liu, Q. 2010. Effects of water regime during rice-growing season on annual direct $\mathrm{N}_{2} \mathrm{O}$ emission in a paddy rice-winter wheat rotation system in southeast China. Science of the Total Environment, 408, 906-913.

Liu, C.Y., Wang, K., Meng, S.X., Zheng, X.H., Zhou, Z.X., Han, S.H., Chen, D. \& Yang, Z.P. 2011. Effects of irrigation, fertilization and crop straw management on nitrous oxide and nitric oxide emission from a wheat-maize rotation field in northern China. Agriculture, Ecosystems and Environment, 140, 226-233. 
Mackenzie, A.F., Fan, M.X. \& Cadrin, F. 1998. Nitrous oxide emission in three years as affected by tillage, corn-soybean-alfalfa rotations and nitrogen fertilization. Journal of Environment Quality, 27, 698-703.

Pelster, D.E., Larouche, F., Rochette, P., Chantignu, M.H., Allaire, S. \& Angers, D.A. 2011. Nitrogen fertilization but not soil tillage affects nitrous oxide emissions from a clay soil under a maizesoybean rotation. Soil and Tillage Research, 115, 16-26.

Robertson, G.P., Paul, E.A. \& Harwood, R.R. 2000. Greenhouse gases in intensive agriculture: contributions of individual gases to the radiadtive forcing of the atmosphere. Science, 289, 1922-1925.
Snyder, C.S., Bruulsema, T.W., Jensen, T.L. \& Fixen, P.E. 2009. Review of greenhouse gas emissions from crop production systems and fertilizer management effects. Agriculture, Ecosystems and Environment, 133, 247-266.

Tenuta, M. \& Sparling, B. 2011. A laboratory study of soil conditions affecting emissions of nitrous oxide from packed cores subjected to freezing and thawing. Canadian Journal of Soil Science, 91, 223-233.

Wang, W.J. \& Dala, R.C. 2006. Carbon inventory for a cereal cropping system under contrasting tillage, nitrogen fertilisation and stubble management practices. Soil and Tillage Research, 91, 68-74. 